Miyanti, Cyrli Yunita. 2016. Konflik dalam relasi sosial masyarakat Jawa dan Lampung di wilayah transmigrasi (studi kasus di Desa Bandar Agung Kecamatan Bandar Sribhawono Kabupaten Lampung Timur). Semarang: Universitas Negeri Semarang

Novianto, Arief. 2016. 'Pergulatan Gerakan mahasiswa dan Kritik Terhadap Gerakan Moral'. Indonesia Bergerak II, Yoyakarta: Pustaka Pelajar

Moertopo, Ali. 1974. Strategi Politik Nasional. Jakarta: Penerbit CSIS

Poesponegoro, Marwati Djoened dan Nugroho Notosusanto [eds]. 1991. Sejarah Nasional Indonesia VI. Jakarta: Balai Pustaka.

Putro, Aryanto Yahya, Hamdan Tri Atmaja dan Inu Sodiq, 2017. Konflik Rasial Antara Etnis Tionghoa Dengan Pribumi Jawa di Surakarta Tahun 1972-1998. Journal of Indonesian History, Vol. 6 No. 1

Prasetyo, Laurentius Yananto Andi. 2013. Peran Tokoh Lintas Agama dalam Menangkal Gerakan Radikalisme Agama dan Implikasinya Terhadap Ketahanan Wilayah. Jurnal Ketahanan Nasional. Vol. 19 No. 3

Priyatmoko, Heri. 4 Oktober 2016. Tragedi 1965 di Solo. Joglosemar

Ramdhon, Akhmad. 2016. Merayakan Negara Mematrikan Tradisi: Narasi Perubahan Kampung-Kota di Surakarta. Yogyakarta: Buku Litera

Raillon, Francois. 1985. Politik dan Ideologi Mahasiswa Indonesia: Pembentukan dan Konsolidasi Orde Baru, 1966-1974. Jakarta: Penerbit LP3ES, Terjemahan. Rajab, Budi. (2004).

Sari, Ira Permata. 2014. Konflik Perbatasan Pemerintah Daerah (studi kasus: perebutan Gunung Kelud antara pemerintah daerah Kabupaten Blitar dan Kabupaten Kediri). Malang: Jurnal Ilmu Pemerintahan, Vol. 1 No. 1

Saunders, Joseph. 1998. Academic Freedom in Indonesia. USA: Human Rights Watch

Schafer, Stephen. 1966. The Victim and His Criminal - "Victimology.". Massachusetts: Northeastern University

Setiadi, Elly M dan Usman Kolip. 2011. Pengantar sosiologi: pemahaman fakta dan gejala permasalahaan sosial: teori, applikasi dan pemecahannya. Yogyakarta: Kencana

Suseno, Franz Magnis. 2003. Etika Jawa, Sebuah Analisa Falsafi tentang Kebijaksanaan Hidup Jawa. Jakarta: PT. Gramedia Pustaka Utama.

Tambunan, Ariffin Sari Sarungalan. 1984. Pejuang dan prajurit: konsepsi dan implementasi dwifungsi ABRI. Jakarta : Penerbit Sinar Harapan

Tarmidi, Lepi T., 1999. Krisis Moneter Indonesia : Sebab, Dampak, Peran IMF dan Saran. Buletin Ekonomi Moneter Indonesia, Vol. 1 No. 4

Tim ISSI dkk. 2010. Katalog Buku Terlarang dan Sejarahnya: dari Tahun 1950-2010. Jakarta: ISSI dan Elsam.

Waluyo, Bambang. 2011. Viktimologi Perlindungan Korban dan Saksi. Jakarta: Sinar Grafika

Yusuf, Iwan Awaludin, dkk. 2010. Pelarangan Buku di Indonesia sebuah paradoks Demokrasi dan Kebebasan Berekspresi. Yogyakarta: PR2Media

Zamroni, A dan Andin, M., 1998. Pahlawan reformasi: catatan peristiwa 12 Mei 1998. Jakarta: Pabelan Jayakarta

Koran:

Kompas, 9 Mei 1997

Kompas, 9 Januari 1998

Kompas, 16 Januari 1996

Solopos, 5 Mei 1998

Solopos, 7 Mei 1998

Solopos, 13 Mei 1998 


\title{
PERUBAHAN SOSIAL EKONOMI PEKERJA SEKS KOMERSIAL REMAJA DI PANTI PELAYANAN SOSIAL WANITA "WANODYATAMA" SURAKARTA
}

\author{
Dewi Saraswati ${ }^{1}$, Rahesli Humsona ${ }^{2}$ \\ Program Studi Sosiologi Fakultas Ilmu Sosial dan Politik \\ Universitas Sebelas Maret Surakarta Indonesia \\ Email1ㄹ. dewisaraswati@gmail.com,Email²: rahesli64@gmail.com
}

\begin{abstract}
This study aims to describe the social economic changes of teenage prostitution. This research was conducted at the "Wanodyatama" Women's Social Services Institution Surakarta because most of the rehabilitated women were teenagers. The theory used is the theory of social practice according to Bourdieu. This type of research is a qualitative descriptive study by the phenomenological method, where a type of research that seeks to describe the socio-economic changes of teenagers prostitution. Sources of data in this study are primary and secondary. Data collection techniques were carried out by means of observation, interviews and documents. Sources of data obtained using purposive sampling technique. The validity data to use data triangulation. The data analysis technique used is an interactive analysis model developed by Miles and Huberman. The results of research that contain facts about teenagers who become prostitute have several factors that habitus, capital and realm. Social changes that occur are changes in the person, social structure, structural functions, relations between different structures, and the emergence of new structures. In addition there are also four components of economic change attended by informants, namely education, social status, income, and income contribution. During the reform of the rehabilitation process at Institution with the approval of the entire set of processes and guidance provided, informants shifted the change in a positive direction because it showed the relationship of services and social improvements intended for prostitute was very useful and beneficial. Self-esteem, self-confidence, social responsibility in carrying out social tasks and most importantly can realize work that has been done is a community disease that must be overcome because work can damage the morale of nation.
\end{abstract}

Key word: socio-economic changes, teenage prostitution, empowerment

Abstrak: Penelitian ini bertujuan untuk menggambarkan perubahan sosial ekonomi PSK
remaja. Penelitian ini dilakukan di Panti Pelayanan Sosial Wanita "Wanodyatama" Surakarta
karna sebagian besar wanita yang direhabilitasi merupakan remaja. Teori yang digunakan
yaitu teori praktik sosial menurut Bourdieu. Jenis penelitian yang digunakan adalah penelitian
deskriptif kualitatif, dengan metode fenomenologi, dimana penelitian ini berusaha
menjabarkan perubahan sosial ekonomi remaja mulai dari sebelum menjadi PSK, saat
menjadi PSK dan pada saat berada di panti rehabilitasi. Sumber data dalam penelitian ini
yaitu data primer, dan sekunder. Teknik pengumpulan data dilakukan dengan cara observasi,
wawancara dan dokumen. Sumber data diperoleh dengan menggunakan teknik purposive
sampling. Validitas data yang digunakan yaitu triangulasi data. Teknik analisis data yang
digunakan yaitu model analisis interaktif yang di kembangkan oleh Miles dan Huberman. 
Hasil penelitian menyebutkan bahwa penyebab remaja menjadi PSK memiliki beberapa faktor yakni mengenai habitus, modal dan ranah. Perubahan sosial yang dialami yaitu perubahan dalam personel, adanya perubahan relasi dalam struktur sosial, perubahan dalam fungsi - fungsi struktur, perubahan dalam hubungan antar struktur yang berbeda, dan kemunculan struktur yang baru. Selain itu terdapat pula empat komponen perubahan ekonomi yang dialami yaitu pendidikan, status sosial, pendapatan, dan alokasi pendapatan. Selama menjalani proses rehabilitasi di Panti Pelayanan Sosial Wanita "Wanodyatama" Surakarta dengan menjalani seluruh rangkaian proses dan bimbingan yang diberikan, informan mengalami perubahan ke arah yang positif karena realitas menunjukan bahwa adanya kegiatan pelayanan dan rehabilitasi sosial yang diperuntukkan bagi PSK remaja sangat bermanfaat dan mengalami perubahan untuk mengembalikan harga diri, kepercayaan diri, tanggungjawab sosial dalam melaksanakan fungsi sosialnya dan yang paling penting dapat menyadarkan bahwa pekerjaan yang selama ini dilakukan merupakan penyakit masyarakat yang harus diberantas karena pekerjaan tersebut bisa merusak moral bangsa.

Kata kunci : perubahan sosial ekonomi, PSK remaja, pemberdayaan.

\section{PENDAHULUAN}

Anak - anak mendapatkan perhatian khusus dari Pemerintah yaitu pembangunan berkelanjutan dimulai dari anak-anak. Pada kenyataan yang terjadi sekarang adalah jumlah anak yang menjadi korban Eksploitasi Seksual Komersial Anak (ESKA) semakin banyak dan jumlah penyebaran pun diperkirakan hanya bisa dihitung di permukaan. Di Indonesia pada tahun 2010 tercatat $40.000-70.000$ anak telah menjadi korban ESKA. Mayoritas dari mereka dipaksa bekerja dalam perdagangan seks. Praktik-praktik tersebut terutama berlangsung di pusat prostitusi, tempat hiburan, karaoke, panti pijat, pusat perbelanjaan, dan lain-lain (Budiyawati, 2007). Tetapi banyak faktor yang menyebabkan remaja - remaja tersebut tetap bertahan melakoni profesinya sebagai pelacur, Saptari (Suyanto, 2010) menyebutkan paling tidak ada tiga faktor yang menyebabkan seorang remaja yang menjadi korban eksploitasi tetap bertahan menjadi pelacur. Pertama, karena keadaan ekonomi atau kondisi kemiskinan. Kedua, karena pandangan tentang seksualitas yang cenderung menekankan arti penting keperawanan sehingga tidak memberi kesempatan bagi perempuan yang sudah tidak perawan kecuali masuk kedalam peran yang diciptakan untuk mereka. Ketiga, karena system paksaan dan kekerasan. Stastisktik menunjukan, bahwa kurang lebih $75 \%$ dari jumlah pelacuran adalah wanita - wanita muda dibawah umur 30 tahun. Mereka itu pada umumnya memasuki dunia pelacuran pada usia yang muda, yaitu 1324 tahun dan yang paling banyak ialah usia 17-21 tahun (Kartono, 2009).

Masalah tersebut juga dimiliki oleh daerah Jawa Tengah. Jawa Tengah merupakan salah satu daerah yang banyak dengan keberadaan pekerja seks komersial. Tak sedikit hal yang dilakukan pemerintah dalam menangani masalah tersebut. Kesadaran akan kondisi permasalahan tersebut, maka Dinas Sosial Provinsi Jawa Tengah melalui Panti Pelayanan Sosial Wanita "Wanodyatama" Surakarta untuk melaksanakan pelayanan dan kesejahteraan sosial rehabilitasi sosial bagi penyandang masalah kesejahteraan sosial yaitu wanita tuna susila. Dengan latar belakang tersebut, maka judul yang ingin diangkat yaitu "Perubahan Sosial Ekonomi Pekerja Seks Komersial Remaja di Panti Pelayanan Sosial Wanita "Wanodyatama" Surakarta. Dimana peneliti ingin mengetahui apa saja faktor remaja terjun 
untuk menjadi pekerja seksual komersial, lalu seperti apa perubahan sosial dan ekonomi pada saat anak tersebut menjadi pekerja seks komersial.

\section{METODE PENELITIAN}

Penelitian ini dilakukan di kota Surakarta tepatnya di Panti Pelayanan Sosial Wanita "Wanodyatama" Surakarta. Penelitian ini dilaksanakan pada bulan Mei 2019 - Juli 2019. Persiapan penelitian dilakukan dengan membuat surat ijin penelitian serta menyusun instrument penelitian (interview guide). Penelitian ini adalah penelitian kualitatif dengan pendekatan studi fenomenologi. Teknik pengambilan sampel dengan menggunakan purposive sampling dengan memilih informan yang dianggap relevan dengan tema penelitian. Setelah itu pengumpulan data dilakukan dengan cara observasi, wawancara mendalam serta dokumentasi. Untuk menguji data menggunakan triangulasi data. Sedangkan analisis data, penyajian data, dan diakhiri dengan penarikan kesimpulan (Sutopo, 2002).

\section{HASIL DAN PEMBAHASAN}

\section{Faktor Penyebab PSK Remaja}

1. Habitus, tiap tempat memiliki kebiasaan yang berbeda-beda, karena tempat berkumpulnya orang-orang memiliki logika berbeda dan struktur keharusan serta relevansi yang diterima sebagai adanya yang merupakan pandangan terhadap sesuatu. Jika lingkungan tempat tinggal memiliki kebiasaan untuk terus tertarik terhadap hiburan malam atau mereka tertarik terhadap PSK remaja, maka secara otomatis remaja-remaja yang ada disekitar akan tertarik untuk ikut bersama dengan kebiasaan tempat tersebut. Tanpa mereka sadari setiap orang akan membawa habitusnya untuk kemudian dituangkan dalam pergaulan antar pribadi. Untuk remaja yang awalnya bertempat tinggal diluar habitus tersebut dan akhirnya berada dalam lingkungan yang sama maka agen lainnya dengan kekuatan habitus dan modalnya akan mempengaruhi pendatang baru tersebut. Pendatang baru tersebut akan secara otomatis terdominasi oleh mereka yang memiliki habitus yang kuat dalam wilayah tersebut.

2. Modal, dari berbagai faktor yang melatarbelakangi alasan kenapa para remaja menjadi PSK, dapat dikatakan bahwa faktor-faktor tersebut sangat variatif (ekonomi, kultural, sosial, simbolik) yang membuat mereka bergelut dibidang itu. Dalam berbagai faktor tersebut, para PSK mempertahankan perilakunya secara tidak sadar kemudian diinternalisasikan kepada seluruh orang yang belum pernah menjadi PSK terpaksa mengikuti mereka melalui struktur yang ada. Sejak kecil, para remaja dipacu untuk sukses dan mencari uang demi untuk menyambung hidup.

3. Ranah, sejak kecil mereka mulai mengenal lingkungan sosial dan keinginan untuk menjadi seperti mereka karena gambaran kesuksesan dan kenikmatan memperoleh banyak uang. Fenomena ini begitu jelas. Perubahan remaja menjadi PSK menjadi hal yang sangat biasa dan memang harus terjadi untuk memenuhi kebutuhan atau gaya hidupnya. Dalam interaksi sosial sendiri, kekuasan yang berpola dalam tempat dan waktu akan membentuk dominasi, tergantung dengan modalitas. Perlu diperhatikan disini, bahwa dalam setiap hubungan atau interaksi sosial selalu ada yang mendominasi, yang menjadi faktor dari penyebab pengambilan keputusan para remaja untuk menjadi PSK. Dalam interaksi sosial ada pula yang disebut dengan sanksi. Sanksi yang berpola dalam 
tempat dan waktu akan membentuk legitimasi (dasar pembenaran), dalam kasus ini para orang tua membenarkan praktek prostitusi remaja.

\section{Perubahan Sosial dan Ekonomi PSK Remaja Perubahan Sosial}

Penjelasan teori Sztompka ini menunjukkan bahwa perubahan-perubahan sosial sangat berhubungan dengan perubahan struktur ketimbang tipe lain, di mana perubahan struktur lebih mengarah kepada perubahan sistem. Adapun tipe - tipe perubahan sosial menurut Sztompka, berdasarkan hasil dari penelitian yang telah diolah sebagai berikut :

1. Perubahan dalam personel (changes in personnel). Berkaitan dengan perubahan peran dan individu individu baru dalam sejarah kehidupan manusia yang berkaitan dengan keberadaan struktur. Perubahan personel yang dirasakan yaitu pada sikap yang dimiliki informan, karena sebelum berada di Panti Rehabilitasi mereka memiliki pribadi yang bebas yang melakukan apapun semau nya saja, namun memiliki tanggung jawab untuk menghidupi keluarganya. Setelah berada di Panti mereka merasakan kehidupan yang tenang dan merasa lebih sehat hal ini disebabkan karena ada nya interaksi dengan para pembimbing Panti, tetapi mereka juga merasakan kesedihan karena dengan ada nya mereka di Panti mereka harus meninggalkan keluarga serta tidak dapat membiayai keluarganya sampai waktu yang cukup lama.

2. Adanya perubahan relasi dalam struktur sosial. Menyangkut hubungan hubungan peran (role relationships) misalnya perubahan hubungan peran dalam keluarga. Perubahan peran yang dialami oleh ketiga informan yaitu pertama ia memiliki peran sebagai anak yang kebutuhannya di tanggung oleh orang tua nya, namun setelah ia bekerja status tersebut berubah sebagai tulang punggung keluarga dan berperan sebagai seorang PSK, setelah itu perubahan kembali dialami saat mereka tertangkap oleh Satuan Polisi Pamong Praja (Satpol PP) dan dibawa ke Panti rehabilitasi. Status tersebut berubah kembali menjadi Penerima Manfaat, yang memiliki peran menjalani serangkaian kegiatan yang telah di siapkan oleh Panti untuk agar dapat berubah menjadi lebih baik dimata masyarakat.

3. Perubahan dalam fungsi-fungsi struktur (changes in the functions of structures), yakni berkaitan dengan apa dan bagaimana masyarakat melakukan sesuatu. Dari ketiga informan ada dua yang memiliki lingkungan yang sama, yaitu dapat dikatakan bahwa fungsi PSK remaja dalam lingkungannya sebagai penyakit sosial yang harus segera di obati, setelah itu fungsi tersebut berubah menjadi pasien ketika para PSK remaja berada di panti pelayanan sosial "Wanodyatama" Surakarta karena disana merupakan tempat untuk para PSK kembali lagi memulihkan harga dirinya di tempat mereka tinggal.

4. Perubahan dalam hubungan antar struktur yang berbeda. (changes in the relationships between different structures). Pada perubahan ini membawa dampak ke informan pada perubahan penghasilan yang didapat para PSK. Awalnya sebelum berada di panti rehabilitasi, kondisi ekonomi mereka membaik, tapi setelah direhabilitasi mereka merasa kondisi ekonominya menurun. Hal ini menunjukkan adanya perubahan hubungan antara struktur lingkungan yang berbeda, hubungan yang dimaksud disini adalah hubungan antara lingkungan dengan keadaan ekonomi para PSK. Selain itu adanya perubahan lain dalam struktur baru dibanding sebelumnya, yaitu perubahan dalam menjalani hidup lebih sehat serta motivasi untuk berubah. Karena kondisi yang berbeda, lingkungan serta personal yang dihadapi berbeda membuat pola hubungan juga menempatkan mereka dalam posisi yang berbeda dari sebelumnya.

5. Kemunculan struktur baru (the emergence of new structures. Setelah dapat menjalani kehidupan sebagai pelacur dan sudah terbiasa dengan dunia prostitusi, mereka mau tidak 
mau harus menghadapi munculnya struktur yang baru kembali. Struktur tersebut yaitu Panti Pelayanan Sosial Wanita "Wanodyatama" Surakarta. Dimana struktur tersebut mengharuskan informan mengikuti kegiatan bimbingan - bimbingan yang telah disiapkan. Dengan adanya bimbingan - bimbingan tersebut perubahan pun dirasakan oleh informan yaitu merasakan hidup yang lebih tenang dan sadar bahwa pekerjaan yang dijalaninya selama ini salah karena bertentangan dengan norma adat dan agama.

Perubahan sosial yang dialami informan dengan adanya lingkungan yang baru yaitu Panti Pelayanan Sosial Wanita "Wanodyatama" Surakarta mampu membawa bentuk sosialisasi yang baru dan merubah cara bersikap dan berpikir karena adanya pengetahuan terhadap hasil interaksi tersebut. Lingkungan ini pun membawa dampak yang baik terhadap ketiga informan, dari sana lah mereka sadar dan ingin merubah kehidupan yang selama ini dilakukan. Hal tersebut berorientasi bahwa jika struktur berubah akan mengakibatkan semua unsur dalam masyarakat akan berubah. Sejalan dengan itu, bukti-bukti hasil wawancara juga sependapat bahwa suatu kondisi sosial yang berubah dalam masyarakat akan mengakibatkan perubahan terhadap yang lain, dalam hal ini kondisi sosial sebelum berada di panti dan sesudah dipanti.

\section{Perubahan Ekonomi}

Perubahan sosial selalu terjadi dan mencakup semua bidang. Salah satunya adalah bidang ekonomi. Perubahan ekonomi berdasarkan teori Abdulsyani (1994) menyebutkan bahwa ada empat komponen yang berkaitan dengan konsepsi ekonomi, diantaranya, pendidikan, status sosial, pendapatan, dan alokasi pendapatan, berikut pembahasan mengenai perubahan ekonomi yang akan dikupas satu satu berdasarkan data yang penulis dapat melalui informan :

1. Pendidikan, merupakan suatu transformasi warisan budaya seperti pengetahuan, nilainilai dan keterampilan-keterampilan yang salah satunya disalurkan melalui lembagalembaga pendidikan. Peranan pendidikan dalam drama kehidupan dan kemajuan umat manusia semakin penting. Ini dikarenakan semakin berkembangnya peradaban manusia yang secara otomatis berkembang pula permasalahan hidup yang dihadapi manusia. Pendidikan formal yang dimiliki informan hanya sebatas lulusan SD dan ada yang sampai kelas 2 SMP. Hal itu pula yang dijadikan alasan mereka memilih pekerjaan sebagai PSK, karena dapat menemukan jalan pintas untuk mengumpulkan uang banyak tanpa memperhatikan pendidikan yang dimiliki. Setelah menjalani pekerjaan keterampilan yang dimiliki informan yaitu menggoda dan melayani para pria hidung belang. Namun setelah itu merekan mendapatkan pendidikan yang membawa mereka pada pengetahun baru akibat dari berbagai materi yang mereka dapatkan selama di panti. Pendidikan ini membawa mereka akan kesadaran tentang jenis pekerjaan yang mereka jalani sebelumnya tidak benar. Akibat lain dari pengetahuan yang didapat selama menjalani pendidikan adalah adanya keinginan untuk tidak menjalani pekerjaan yang sama

2. Status sosial, semua orang pasti menginginkan untuk dapat memperoleh status sosial yang tinggi dan penghasilan yang lebih tinggi daripada apa yang pernah dicapai oleh orangtuanya. Semua orang pasti menginginkan suatu kehidupan yang serba kecukupan, bahkan kalau mungkin berlebihan.. Ketiga informan memiliki kesamaan yaitu sebelum berada di panti status sosial yang mereka kejar adalah kehidupan yang berkecukupan, namun setelah berada di panti pola status mereka berubah, lebih berkeinginan untuk mencari ketenangan dan hidup sehat. 
3. Pendapatan, perubahan ini jelas dialami oleh informan, hal tersebut dipengaruhi oleh faktor lingkungan yang mereka tinggali. Karena lingkungan yang berbeda pada saat sebelum menjadi PSK, saat menjadi PSK, atau saat di rehabilitasi, hal itu membuat sangat berpengaruh terhadap kehidupan finansial yang dialami informan. Pendapatan yang didapatkan sekitar Rp. 200.000 - Rp. 300.000 per harinya dengan mejalani pekerjaan Gabriel sebagai pemandu karaoke, Vanesa sebagai Pekerja Seks Komersial, dan Saras sebagai terapis di salon ++. Lalu kehidupan berkecukupan mereka harus berakhir di Panti rehabilitasi, dimana mereka bahkan tak memperoleh uang sepeserpun. Perbedaan pendapatan ini menyebabkan berbagai reaksi bagi para PSK, diantaranya dilema, sedih, dan takut menatap masa depan. Disinilah fungsi bagi para pembimbing untuk lebih menekankan pada keterampilan dan spiritual. Sehingga mereka merasa yakin bahwa rejeki sudah ada yang mengatur dan tak perlu takut akan masa depan.

4. Alokasi pendapatan, komponen berikutnya yang berubah adalah alokasi pendapatan. Pada saat sebelum menjadi PSK informan tidak memiliki pendapatan tetap sehingga tidak mengalokasikan pendapatannya terhadap suatu hal apapun. Dan setelah bekerja sebagai PSK, pendapatan bersih yang di dapatkan dialokasi kan untuk keperluan pribadi nya dan juga untuk diberikan kepada orang tua nya.

"Kalo harian sih, 50ribu buat manajer, saya 300ribu, 200ribu buat kebutuhan saya, 100ribu saya kumpulkan selama 30 hari buat kirim ke orang tua " (wawancara Gabriel 16 Mei 2019.

Adanya perbedaan alokasi pendapatan sebelum dan sesudah di panti membuat para pekerja sosial seperti pembimbing lebih memfokuskan untuk meyakinkan mental para PSK. Karena informan merupakan sumber pendapatan bagi keluarga, dan saat sekarang di rehab informan tidak dapat memberikan uang unuk keluarganya.

\section{Pemberdayaan Wanita di Panti Pelayanan Sosial Wanita "Wanodyatama" Surakarta}

Mengacu pada asumsi Moeljarto Tjokrowinoto mengenai konsep pemberdayaan, maka yang pertama yaitu pemberdayaan menekankan pada proses pengalihan daya kepada masyarakat atau individu tersebut lebih berdaya. Hal ini dibuktikan dengan para PSK remaja yang status nya menjadi Penerima Manfaat di Panti yang mengikuti serangkaian serangkaian bimbingan dari Panti. Bimbingan - bimbingan yang diberikan oleh Panti yakni bimbingan fisik, bimbingan mental, bimbingan sosial, dan bimbingan keterampilan. Seperti pada kutipan wawancara berikut:

"Jadi selama disini saya lebih merasa bersemangat dan menjalani hidup sehat, terus juga dapat pengetahuan masak” (Wawancara dengan Vanesa, 16 Mei 2019)

Bimbingan tersebut bukan tanpa tujuan, melainkan memiliki tujuan untuk menjaga kesehatan jasmani dan rohani para penerima manfaat melalui bimbingan fisik dan bimbingan mental, memahami norma dan nilai yang ada dimasyarakat melalui bimbingan sosial serta memberikan keterampilan dengan harapan menjadi lebih berdaya dan berkembang ilmu serta kreativitasnya sehingga nantinya ia diharapkan dapat memajukan kehidupannya, keluarganya maupun lingkungan sekitarnya. Kedua, menyangkut proses stimulus, dorongan serta motivasi maka panti berperan penting dalam pembentukan dan pengembangan motivasi pada para Penerima Manfaat sehingga mereka mau dan mampu dalam mengikuti bimbingan keterampilan yang diberikan. Dukungan fasilitas beserta instruktur atau pengajar yang profesional dapat menjadi dorongan tersendiri bagi para Penerima Manfaat karena selain 
mereka dapat belajar mengenai keterampilan dari para instruktur, mereka juga dapat belajar melalui pengalaman-pengalaman instruktur sehingga diharapkan hal tersebut dapat meningkatkan motivasi bagi para Penerima Manfaat.

\section{PENUTUP}

Berdasarkan serangkaian uraian pada bab - bab terdahulu dan mengacu pada perumusan masalah serta tujuan penelitian dapat disimpulkan bahwa :

1. Faktor penyebab PSK remaja yaitu, yang pertama ialah habitus. Habitus menjadi faktor remaja menjadi PSK karena jika lingkungan tempat tinggal memiliki kebiasaan untuk terus tertarik terhadap hiburan malam atau mereka tertarik terhadap PSK remaja, maka secara otomatis remaja-remaja yang ada disekitar akan tertarik untuk ikut bersama dengan kebiasaan tempat tersebut. Faktor yang kedua yaitu karena modal. Faktor modal yang paling kuat untuk menjadi penyebab remaja menjadi PSK yaitu modal simbolik karena sejak kecil, anggapan sukses menurut mereka yaitu dengan memiliki uang banyak dan dapat memenuhi kebutuhan hidup dengan mudah. Maka dengan begitu mereka dapat dengan mudah memutuskan untuk menjadi PSK agar bisa memiliki banyak uang. Faktor terkhir yaitu sejak kecil mereka mulai mengenal lingkungan sosial dan keinginan untuk memiliki hidup berkecukupan. Fenomena ini begitu jelas. Perubahan remaja menjadi PSK menjadi hal yang sangat biasa dan memang harus terjadi untuk memenuhi kebutuhan atau gaya hidupnya.

2. Perubahan sosial dan ekonomi pada PSK remaja yang berada di Panti Pelayanan Sosial Wanita Wanodyatama Surakarta. Perubahan sosial merupakan segala bentuk perubahan yang terjadi pada masyarakat. Perubahan sosial yang dialami dengan adanya lingkungan yang baru yaitu Panti Pelayanan Sosial Wanita "Wanodyatama" Surakarta mampu membawa bentuk sosialisasi yang baru dan merubah cara bersikap dan berpikir karena adanya pengetahuan terhadap hasil interaksi tersebut. Lingkungan ini pun membawa dampak yang baik, dari sana lah mereka sadar dan ingin merubah kehidupan yang selama ini dilakukan. Hal tersebut berorientasi bahwa jika struktur berubah akan mengakibatkan semua unsur dalam masyarakat akan berubah. Pada perubahan di bidang ekonomi yang terjadi yaitu dari segi pendapatan, dimana pada saat menjadi PSK, mereka memiliki pendapatan rata - rata Rp.200.000 perhari nya, sedangkan pada saat di rehabilitasi di Panti tidak ada lagi pendapatan yang diterima dan tentunya hal itu berdampak pada alokasi pendapatan yang dialami oleh informan, karena dengan tidak ada nya pendapatan yang dimiliki tidak ada pula uang yang harus dialokasi kan seperti biasanya.

3. Pemberdayaan wanita di Panti Pelayanan Sosial Wanita "Wanodyatama" Surakarta. Proses rehabilitasi di Panti tersebut memiliki cara yaitu Panti memberikan bimbingan bimbingan kepada Penerima Manfaat (PM). Bimbingan tersebut bukan tanpa tujuan, melainkan memiliki tujuan untuk menjaga kesehatan jasmani dan rohani para penerima manfaat melalui bimbingan fisik dan bimbingan mental, memahami norma dan nilai yang ada di masyarakat melalui bimbingan sosial serta memberikan keterampilan dengan harapan keluarnya para Penerima manfaat dapat bekerja dengan keterampilan yang di dapatkan di Panti. Sehingga realitas menunjukan bahwa adanya kegiatan pelayanan dan rehabilitasi sosial yang diperuntukkan bagi PSK remaja sangat bermanfaat dan mengalami perubahan untuk mengembalikan harga diri, kepercayaan diri, tanggung jawab sosial dalam melaksanakan fungsi sosialnya dan yang paling penting dapat 
menyadarkan bahwa pekerjaan yang selama ini dilakukan merupakan penyakit masyarakat yang harus di berantas karena pekerjaan tersebut bisa merusak moral bangsa ini.

\section{DAFTAR PUSTAKA}

Abdulsyani. 1994. Sosiologi (skematik, teori dan terapan). Jakarta : Bumi Aksara.

Anwar, Yesmil dan_Andang. 2013. Kriminologi. Bandung : PT. Refika Aditama.

BAPPENAS dan UNICEF. 2017. Laporan Baseline SDG tentang Anak - anak di Indonesia.

Budiyawati, Hening dkk. 2007. Analisis Situasi Eksploitasi Seksual Komersial terhadap Anak di Semarang dan Sekitarnya. Semarang : Yayasan Setara Kementrian Pemberdayaan Perempuan.

Caraboi, Adrian Daniel dan Christina Fierbinteanu. 2015. The impact of commercial sex work in Brasov Area. Geopolitics, History, and International Relations. Volume 7(2), pp. 362-372, ISSN 1948-9145

Creswell. 1998. Qualitative inquiry: Choosing Among Five Tradtions. Sage Publication.

Darmasih, Ririn. 2009. Faktor yang Memepengaruhi Perilaku Seksual Pranikah pada Remaja SMA di Surakarta. Skripsi: Fakultas Kesehatan Masyarakat UMS.

Djojohadikusumo, Soemitro. 1985. Perdagangan dan Industri dalam Pembangunan. Jakarta : LP3ES.

Field, John. 2010. Modal Sosial. Yogyakarta: Kreasi Wacana.

Halim, Abdul dan Muhammad Syam Kusufi. 2014. Akuntansi Keuangan Daerah. Edisi 4. Jakarta: Salemba Empat.

Harker, Richard dkk. 2009. (Habitus $x$ Modal) + Ranah = Praktik. Yogyakarta: Jalasutra.

Haryatmoko. 2003. Menyingkap Kepalsuan Budaya Penguasa. Basis No. 11-12, Th.52, hal. 4-22.

Henderina. 2012. Wanita Pekerja Seks Komersial. Skripsi. Universitas Hasanudin Makasar.

Hounmenou, Charles. 2016. Exploring Child Prostutition in a Major City in the West African Region. Journal Child Abuse \& Neglect. Volume 59, September, pages 26-35.

Hull, Terence H. 1997. Pelacuran di Indonesia. Jakarta : Pustaka Sinar Harapan Bekerja sama dengan The Ford Foundation.

Kadir, Hatib Abdul. 2007. Tangan Kuasa dalam Kelamin Telaah Homoseks, Pekerja Seks dan Seks Bebas di Indonesia. Yogyakarta : Insist Press.

Kartono, Kartini. 1995. Psikologi Anak (Psikologi Perkembangan). Bandung: CV.Mandar Maju.

Kartono, Kartini. 2009. Patologi Sosial jilid 1. Jakarta : PT Rajawali Pers.

Kartono, Kartini. 2014 . Patologi Sosial. Jakarta : PT. Raja Grafindo Persada.

Koentjoro. 2004. On The Spot Tutur dari Sang Pelacur. Yogyakarta: Tinta.

Kristiyana, Martha. 2013. Perilaku Sosial Pekerja Seks Komersial (PSK) di Pasar Hewan, Sleman, Yogyakarta. Skripsi : Universitas Negeri Yogja.

Kusnaedi. 2013. Pendidikan Karakter. Bekasi : Duta Media Utama.

Lubis, Akhyar Yusuf. 2014. Postmodernisme: Teori dan Metode. Jakarta : rajawali pers.

Moleong, Lexy J. 2010. Metodologi Penelitian Kualitatif. Bandung : PT Remaja Rosdaya Karya.

Moleong, Lexy J. 2013.Metodologi Penelitian Kualitatif. Bandung: Remaja Rosdaya Karya.

Puspa, Sagara Asih, Hadiyanto A Rachim, dan Nandang Mulyana. 2015. Upaya Penanganan Pekerja Seks Komersial. Prosiding KS : Riset \& PKM. Volume : 2. Nomor 1. Hal 1-146. ISSN : 2442-4480.

Rakhmat, Jalaludin. 2004. Psikologi Komunikasi. Bandung: PT. Remaja Rosdakarya. 
Ritzer, George. 2003. Sosiologi Ilmu Pengetahuan Berparadigma Ganda. Jakarta: Raja Grafindo Persada.

Ritzer, George. 2012. Teori Sosiologi. Yogyakarta : Pustaka Pelajar.

Sadono, Sukirno. 2010. Ekonomi Pembangunan: Proses, Masalah, dan Dasar Kebijakan. Jakarta: Kencana Prenada Media Group.

Saraswati, Dewi. 2018. Pemberdayaan Wanita Tuna Susila dalam Program Rehabilitasi Sosial di Panti Pelayanan Sosial Wanita "Wanodyatama” Surakarta. Laporan Magang Sosiologi.

Sarwono, Sarlito Wirawa. 2006. Psikologi Remaja. Jakarta : Rajawali Pers.

Soemardjan, Selo. 1986. Perubahan Sosial di Yogyakarta. Yogyakarta : Gajah Mada University Press.

Sutopo. 2002. Metodologi Penelitian Kualitatif. Surakarta : UNS Press.

Sutopo. 2006. Metodologi Penelitian Kualitatif. Surakarta : UNS Press.

Sutrisno, Mudji dan Hendar Putranto. 2005. Teori - Teori Kebudayaan. Yogyakarya : Kanisius.

Suyanto. 2010. Masalah Sosial Anak. Jakarta : Kencana Prenada Media Group.

Svalastoga, Kaare. 1989. Diferensiasi Sosial. Jakarta : Bina Aksara.

Sztompka, Piotr. 2007. Sosiologi Perubahan Sosial. Jakarta : Prenada Media Group.

Tjokrowinoto, Moeljarto. 2001. Pembangunan Dilema dan Tantangan. Yogyakarta : Pustaka Pelajar.

Umam, Fawaizul dkk. 2006. Membangun Resistensi Merawat Tradisi Modal Sosial Komunitas Wetu Telu. Mataram: Lembaga Kajian Islam dan Masyarakat. 